\title{
An Evaluation of TOEFL Benchmark Policy as an Exit Requirement for Undergraduate Students
}

Endah Anisa Rahma ${ }^{1}$, Rina Syafitri ${ }^{2}$, Veni Nella Syahputri ${ }^{3}$ \& Firman Parlindungan ${ }^{4}$

1,2,3,4 Universitas Teuku Umar, Aceh Barat, Indonesia

\begin{tabular}{|c|c|}
\hline ARTICLE INFO & ABSTRACT \\
\hline $\begin{array}{l}\text { Article history: } \\
\text { Received Nov 28, } 2020 \\
\text { Revised Jan 15, } 2021 \\
\text { Accepted Jan 30, } 2021\end{array}$ & $\begin{array}{l}\text { This study investigated the TOEFL benchmark policy as an exit } \\
\text { requirement for Universitas Teuku Umar students. The research } \\
\text { method used was survey design hereby the data from the } \\
\text { questionnaire and students' TOEFL score were collected. Under the } \\
\text { policy, the students have to pass the standard passing score of } \\
\text { TOEFL to graduate. } 100 \text { non-English maior students from }\end{array}$ \\
\hline $\begin{array}{l}\text { Keywords: } \\
\text { TOEFL } \\
\text { Benchmark Policy } \\
\text { Exit Requirement }\end{array}$ & $\begin{array}{l}\text { Universitas Teuku Umar participated in this study. The results of the } \\
\text { study revealed that the participants gave more positive responses than } \\
\text { negative ones. The extend of approval for this policy seemed more } \\
\text { related to their abilities, awareness of the importance of learning } \\
\text { English, and motivation to learn English. The result from TOEFL } \\
\text { scores taken from } 2018-2019 \text { found that as many as } 58 \% \text { of students } \\
\text { failed to obtain minimum criteria }(>400) \text { while only } 42 \% \text { of them }\end{array}$ \\
\hline $\begin{array}{l}\text { Conflict of Interest: } \\
\text { None }\end{array}$ & $\begin{array}{l}\text { reached } 400 \text { or above. It indicates that Universitas Teuku Umar } \\
\text { students are not ready yet to face this policy. On the other hand, }\end{array}$ \\
\hline $\begin{array}{l}\text { Funding: } \\
\text { None }\end{array}$ & $\begin{array}{l}\text { based on the questionnaire result, most students agreed with the } \\
\text { implementation of TOEFL as an exit requirement, however, a } \\
\text { minimum passing score should be evaluated and a set of students' } \\
\text { needs under the policy should be facilitated. }\end{array}$ \\
\hline
\end{tabular}

Corresponding Author: Endah Anisa Rahma, Faculty of Fisheries and Marine Science, Universitas Teuku Umar. Email: endahanisarahma@utu.ac.id

\begin{tabular}{ll}
\hline C. (C) Endah Anisa Rahma, Rina Syafitri, Veni Nella Syahputri, Firman Parlindungan \\
This is an open access article under the CC BY-SA 4.0 international license.
\end{tabular}

\section{Introduction}

It is widely recognized that English is studied as an international language. English in Indonesia is used in a range of fields such as diplomacy, international trade and industry, science and technology, and education (Huda, 2000). Although English is not used in the official domain, English is still regarded as a priority in Indonesia such as becoming one of the compulsory subjects at school and tertiary level.

TOEFL has been enacted as one of the graduation requirements at Universitas Teuku Umar (UTU) since 2018. Universitas Teuku Umar locates at Meulaboh city, Aceh, Indonesia. It has been declared as a state university since 2014. In line with UTU's vision," becoming a source of inspiration and reference in the development of science, technology, and business in the agro and marine-based industrial sector (agro and marine industry), ranked regionally (2025), national (2040), and international (2060) through innovative, creative and highly competitive research", the university prepares a good quality of English proficiency for UTU's stakeholders. One of the main elements that have to be improved is students' English mastery. English is introduced at the beginning of the semester as a general subject. Then, in 2018, UTU declared the new policy for graduate students to pass the TOEFL test for exit requirement.

Universitas Teuku Umar students who are going to do the script examination are required to obtain a minimum TOEFL score of 400 for all majors. This is stated in the Rector's Decree number 132 / UN59 / EP / 2017 concerning the implementation of the TOEFL score, namely:

1. 400 for graduates of the 2018 and 2019 academic years

2. 450 for graduates of the academic year $2020-2024$

3. 475 for graduates of the academic year above 2025 . 
The graduation requirements are still categorized very low hence it is the first step for students to master the TOEFL and can be improved further. Because 2018 is the first year for students to take TOEFL, students are not certainly familiar with TOEFL and find it difficult to achieve the score determined by the university. Besides, students who have taken English Course at the beginning semester did not study TOEFL. Therefore, it is not surprising that students are not ready to achieve the expected score because there is not enough TOEFL mastery. This policy becomes a new challenge for students in taking the test for the first time.

Based on the researchers' observations when teaching TOEFL courses for students at Teuku Umar University, most of them got below the expected scores (under 400). This was because they had lack of grammar knowledge. As stated by Mahmud (2014) that the students had low abilities in understanding the grammar such as subject pronoun, verb, etc. The study from Mahmud (2014) showed that the TOEFL test was something new for non-English major students so that they committed some grammatical errors. Besides, they also did less practice and less motivation in learning TOEFL because it is not their priority. Besides, students are still not familiar with the TOEFL test. As a result, it has an impact on the low scores they get because students are not used to answering TOEFL test questions. The form of questions in the TOEFL test is not the same as the test questions in their English courses. It is in line with Kasim's case (2016) who found problems from students in the implementation of TOEFL as an exit requirement. According to Kasim, the main problem the students face in answering the TOEFL test are the lower mastery of English and lack of vocabulary.

Grammar is a part that plays an important role in learning English. In the TOEFL test, the grammar test is part two. Lack of grammar mastery is a problem often faced by students learning English as a foreign language apart from vocabulary (Rahma \& Setiyana, 2019). Research conducted by Rahma and Setiyana (2019) shows that the difficulty of students concerning grammar is making sentences that do not match the correct tenses. They often write the form of the verb that does not match the tenses used. This is because students rarely use English outside the classroom so that their mastery of the language is limited. Kasim (2016) also mentioned that the linguistics environment was one of the problems faced by students in learning English so that they did not get enough language exposure because people dominantly speak Indonesian.

Based on the facts and problems described above, researchers are interested in knowing the student's response to the TOEFL policy as a requirement for graduation at their college and the level of student readiness in facing the policy. So, the formulation of the research problem is:

1. How do students respond to the TOEFL benchmark policy at Universitas Teuku Umar?

2. How ready are students for the TOEFL benchmark policy?

\section{Literature Review}

\subsection{TOEFL}

The Test of English as A Foreign Language (TOEFL) is an internationally recognized aspect of the English language proficiency test. Foreign universities such as the United States have set a minimum TOEFL score of 550 for students who are interested in studying in that country. Apart from that, other forms of English proficiency tests such as TOEIC (Test of English for International Communication) and IELTS (International English Language Testing System). In the world of education, TOEFL is very popular because almost all universities in Indonesia apply TOEFL requirements both as an entry and graduation requirement. The TOEFL commonly used in the world of education is the paper-based TOEFL test. TOEFL is recognized as a language proficiency test Official English for undergraduate, master, and doctoral students as academic interests. Sharpe (2004) added TOEFL is also used as a prerequisite for continuing further studies for speakers of English as a foreign language who continue to study abroad with English as their first language.

In the book of ETS (English Testing Program) (2006), it is stated that TOEFL is used as an evaluation of English proficiency as a foreign language of students. Komari (2008) states that the TOEFL consists of three types, namely Paper-based TOEFL, Computer-based TOEFL (CBT), and Internet-based TOEFL (IBT). At Universitas Teuku Umar, students still use the TOEFL PBT or paper-based TOEFL system because this test is considered cheap and easy. Besides, local institutions and companies still accept this TOEFL PBT certificate on the condition that the institution holding the test is an acknowledged or official language institution. According to ETS (2006), there are three types of TOEFL tests, namely:

1. International TOEFL / Official TOEFL. These test scores are valid and recognized in all institutions anywhere in the world.

2. Institutional TOEFL. This TOEFL score is valid and recognized by several institutions. This type of TOEFL is generally used to apply for scholarships, continuing education, applying for jobs, and others. 
3. TOEFL Prediction / TOEFL-like This TOEFL score is only valid and recognized internally by the test administering institution.

The TOEFL test is also used to pre-qualify students for graduation. In general, three types of tests are tested in the TOEFL PBT; listening, structure and written expression, and reading comprehension. TOEFL PBT consists of ITP (Institutional Testing Program) which is held directly by ETS. The second type of PBT is the predictive TOEFL (equivalent) which is commonly used to predict scores as a condition for graduation in college. The purpose of this test is to systematically place students in certain ranking positions, for example from a score of 400 to 677.

\subsection{TOEFL Policy}

According to Friedrich, quoted in Wahab (2004), a policy is an action that leads to the goals of a person or a group of people or a certain government in connection with the obstacles faced so that opportunities are needed to achieve the stated goals. Therefore, the policy is a rule that aims to offer solutions to the obstacles faced. According to Law number 2 of 1989 regarding the education system which states that English is the first foreign language to enter the Indonesian education system. The law clearly states that English is a compulsory subject for secondary and elementary schools. English is also studied as a general subject at the tertiary level in Indonesia. As a general subject, English is studied as an introduction. It does not guarantee students to be able to communicate well and do not have good foreign language skills.

TOEFL at a higher educational institution is managed by an English laboratory or language center. In Indonesia, TOEFL is used for continuing study, promoting job level, getting the job, and graduation requirement. In some countries in Asia, English language policy has been initiated at the macro level in the appearance of the globalization era. This globalization has led to educational policymakers in Asian countries involve the English discourse in for internalization of their own higher education, participation in economic globalization, and development (Hamid \& Nguyen, 2016). Hamid's and Nguyen's study (2016) suggested that English language policy should pay attention to what society need, linguistics point of view, globalization challenge needs, and teachers' skill development.

To improve the use of English in the globalization era, several campuses set a TOEFL score as a graduation requirement. For example, the Rector of the Universitas Teuku Umar stipulated a policy of implementing TOEFL scores for students who would carry out undergraduate sessions. The TOEFL exam is a test that must be taken by all students to fulfill the thesis defense requirements. The problem is, although it is compulsory, the university does not make TOEFL one of the general courses or elective courses that students can take. As a result, many students are not able to face the TOEFL exam well. Indeed, there are general English courses that can be followed, it's just that what is taught in these general subjects is limited to Basic English lessons such as grammar, there are no lessons related to the TOEFL. Because of these problems, this policy needs to be considered and students' perceptions need to be studied to find out the needs and problems they face in the TOEFL test.

The study from Shih (2007) proves that GEPT (General English Proficiency Test) policy that has to be taken by university students in Taiwan for graduation requirement had a limited effect on students' learning English. Despite their autonomous learning improvement, they got frustrated and stressed when failing the test. Shih (2010) also investigated two applied foreign language departments of technological universities in Taiwan. Shih evaluated the one department (department A) that prescribed the English graduation benchmark and another one (Department B) did not apply it. The study found that the reason Department A did not apply the English graduation benchmark because of parental factors and the low students' English proficiency. While Department B believed required the students to pass the English proficiency test to graduate. It is believed that the policy would enhance their students to learn English, help to seek employment after graduation, and be more competitive among universities in Taiwan. Finally, this study confirmed from their lecturer that universities should consider educational factors, school factors, teachers, and students factors before implementing this English requirement.

Shih (2013) investigated the students' attitude toward the English Graduation Benchmark Policy and its impact on students' motivation. The study showed that students wanted to do well on the exam and had the desire to improve their English proficiency. Differences in gender, year of study, academic discipline, English proficiency levels, and test status were more related to students' English abilities in determining their motivation to learn. There are some suggestions provided by Shih: the quality of exit exam, a different set of standards under the policy, appropriate learning strategies, and the connection among curriculum, instruction, and assessment. 
The other studies were conducted by Chen and Squires (2010). Their survey and interview result found that the Standardized English Proficiency Test enhanced Vocational College students' English Proficiency and increased competitiveness in their future career and advanced studies. However, the policy had little or no motivation for students to prepare for the test. This might due to the students' low interest (59\%), low English proficiency $(88 \%)$, and high exam registration fee $(92 \%)$. This study suggested that Higher Education institutions and English lecturers provide more help with general test preparation strategies and technologies to enhance their confidence to pass the test.

Samad and Fitriani (2016) have researched students of the Syiah Kuala University. Their study investigated the level of readiness of Syiah Kuala University students towards the Asean Era Society (MEA) through their TOEFL results. A total of 1916 students of the Syiah Kuala University were taken as the subjects of this study. The data in this study were students' TOEFL scores and interviews. Their TOEFL scores were grouped into two categories: ready ( $>500)$ and unprepared (450-497), $(<450)$. The results showed that only $0.42 \%$ or about 8 students from 1916 were ready to face the MEA. Meanwhile, 1908 was deemed not ready to face the MEA. The results of interviews with the authorities who hold the TOEFL test for students are expected to reach a score of 450 as a condition for the scrip defense. This reason indicated the importance of having good English proficiency, which can be demonstrated through the TOEFL score. The results of the next interview showed that Syiah Kuala University had taken the policy to help students to increase their TOEFL scores through the UP3BI and General English Language Courses (MKU) programs. However, Samad's and Fitriani's study has not yet explained the opinions of students on the TOEFL policy. Thereby the recent study investigated the students' perspective about the implementation of TOEFL score to get a bachelor's degree. In this recent study, the policy of TOEFL implementation was investigated from students' points of view. The researcher wanted to know in depth whether students give a positive or negative response in facing the policy. The questionnaire was adapted from Chen and Squire Study who divided the negative and positive opinions.

\section{Method}

This research is the descriptive qualitative method using the survey. It was conducted at Universitas Teuku U mar. The questionnaire was the primary data and secondary data were in the form of TOEFL scores from the local language center. The subjects of this study were students who had taken the TOEFL test as a thesis defe nse and were completing their thesis. Secondary data in the form of TOEFL scores taken are from 2018 to 20 19 because this policy started in 2018.

Data collection was carried out by distributing questionnaires to students to find out their responses to the TO EFL policy. Besides, the secondary data from student's TOEFL scores is a reference for seeing how many sco res were obtained and then grouped into two categories from the lowest to the highest; Below 400, above 400 . Students whose score below 400 are deemed not to be eligible to do script examination because the qualifyi ng score for graduation is 400 . Meanwhile, those whose score is between 400 or more are considered ready a nd meet the criteria to attend script examination. Based on these groupings, it can be concluded that this stud y classifies student readiness into two categories; ready and not ready. This grouping was adopted from Sama $\mathrm{d}$ and Fitriani (2016).

The questionnaire used was a closed questionnaire consisting of 20 items using a Likert scale of points 1-3 (1 $=$ disagree, 2 = neutral, $3=$ agree) from item 1 to item 20 and using multiple answers where the participants $\mathrm{c}$ an choose more than one items. The results of the questionnaire were analyzed using the percentage of studen $\mathrm{t}$ responses, with the formula described by Arikunto (2006):

$\mathrm{P}=\mathrm{F} / \mathrm{N} \times 100 \%$

Where,

$\mathrm{P}=$ Percentage of questionnaires

$\mathrm{F}=$ Frequency

$\mathrm{N}=$ Number of respondents

This research has begun in May 2020, for the 2019/2020 school year. The subjects of this study were students who had taken the TOEFL test. The data collected is in the form of TOEFL scores from the Language Center. The questionnaire data were also distributed randomly to 110 participants who had taken the TOEFL test and had not.

\section{Results and Discussion}

4.1. Result

4.1.1. Students' Response to the Implementation as a Graduation Requirement

To get a deep understanding related to the TOEFL policy as an exit requirement, 110 students from different majors participated in this study and were asked to fill in the questionnaire. The questionnaire was adapted 
from Al- Rawashdeh (2009), Chen and Squires (2010). The following table showed the questionnaire result from the participants.

The Table 1. Percentage of Participants' Positive Statements to the Implementation of TOEFL

\begin{tabular}{cllcc}
\hline \multirow{2}{*}{ Item } & \multicolumn{1}{c}{ Positive Statements } & \multicolumn{2}{c}{$\mathbf{2}$} & $\mathbf{3}$ \\
\cline { 3 - 5 } & & \multicolumn{3}{c}{ Percentage (\%) } \\
\hline 1. & TOEFL helps me to improve my English proficiency. & 12.6 & 34.6 & 53.6 \\
\hline 2. & $\begin{array}{l}\text { Universities must require students to pass the TOEFL test before } \\
\text { graduation. }\end{array}$ & 27 & 40.5 & 32.4 \\
& $\begin{array}{l}\text { The TOEFL test makes me more aware of the importance of } \\
\text { English. }\end{array}$ & 10.8 & 35.1 & 54.1 \\
\hline $\begin{array}{l}\text { I have been using TOEFL preparation materials for the TOEFL } \\
\text { test. }\end{array}$ & 11.7 & 59.5 & 28.8 \\
\hline 5. & The TOEFL score indicates my English competence. & 12.6 & 48.6 & 38.7 \\
\hline 6. & The TOEFL test can enhance my English ability. & 11.7 & 44.1 & 44.1 \\
\hline 7. & TOEFL can enhance the interest to study abroad. & 8.1 & 34.2 & 57.7 \\
\hline 8. & TOEFL test motivates me to graduate on time. & 13.5 & 54.1 & 32.4 \\
\hline 9. & The English Subject is very helpful to pass the TOEFL test. & 14.4 & 49.5 & 36 \\
\hline 10 & The TOEFL test motivates me to learn English. & 9.9 & 36 & 54.1 \\
\hline
\end{tabular}

Note: 1 = Disagree, $2=$ Neutral, $3=$ Agree

Table 1 shows the students' opinion on the implementation of TOEFL as a graduation requirement. Among 10 items of questionnaires, the three items thought agree by the largest number of respondents that stated The TOEFL can enhance the interest to study abroad (57.7\%), the TOEFL test makes me more aware of the importance of English (54.1\%) and motivates them to learn English (54.1\%). Besides, only one item thought by the smallest number of participants that students have prepared the materials for the test $(28.8 \%)$. While as much as $59.5 \%$ of students had no opinion or neutral about preparation the material for the test and $54.1 \%$ of them also had no opinion about the TOEFL test can enhance them to graduate punctually. It is implied that English influences university students. It can be seen from dominant participants agreed for item 7, 3, and 10. They are aware of English as one of the important languages in this globalization era. However, some students were not confident to convict themselves to item number 4 and 8 since they did not ensure whether they were able to do it or not.

Table 2. Percentage of Participants' Negative Statements to the Implementation of TOEFL

\begin{tabular}{clccc}
\hline \multirow{2}{*}{ Item } & \multicolumn{1}{c}{ Negative Statement } & $\mathbf{2}$ & $\mathbf{2}$ & $\mathbf{3}$ \\
\cline { 3 - 5 } & & 43.2 & 36.9 & 19.8 \\
\hline $\mathbf{1 .}$ & The tuition fee of TOEFL test is expensive & 25.2 & 40.5 & 34.2 \\
\hline $\mathbf{2 .}$ & The time needed for the TOEFL test is very short. & 18.9 & 45 & 36 \\
\hline $\mathbf{3}$ & The TOEFL Test is generally hard. & 40.5 & 33.3 & 26.1 \\
\hline $\mathbf{4 .}$ & I have low motivation in learning English. & 47.7 & 28.8 & 23.4 \\
\hline $\mathbf{5 .}$ & $\begin{array}{l}\text { I do not get benefits in taking the TOEFL test except for an } \\
\text { academic purpose. }\end{array}$ & 29.7 & 36 & 34.2 \\
\hline 6. & $\begin{array}{l}\text { The minimum criteria of TOEFL score for graduation } \\
\text { requirement are very high. }\end{array}$ & 32.4 & 43.2 & 24.3 \\
\hline 7. & $\begin{array}{l}\text { The administrative procedure of the TOEFL test is ambiguous } \\
\text { and complicated. }\end{array}$ & 39.6 & 42.3 & 20 \\
\hline 8. & $\begin{array}{l}\text { The facility and class provided by the language center are not } \\
\text { satisfactory. }\end{array}$ & 22.5 & 44.1 & 33.1 \\
\hline $\mathbf{9 .}$ & I feel stressed about having to pass the TOEFL test. & 18 & 42.3 & 39.6 \\
\hline $\mathbf{1 0}$ & $\begin{array}{l}\text { Standard of TOEFL benchmark as exit graduation is too difficult } \\
\text { for me. }\end{array}$ & &
\end{tabular}

Note: $1=$ Disagree, $2=$ Neutral, $3=$ Agree

Based on table 2 about negative statements, it is demonstrated that the largest number of respondents $(39.6 \%)$ agree that the standard of TOEFL benchmark as exit graduation is too difficult for students. Table 2 shows that the largest number of respondents had no opinion about the difficulty of the TOEFL test (45\%), feeling stress to pass the test $(44.1 \%)$, the time limit for the test $(40.5 \%)$, and disagree with the statement "I do not get benefits in taking TOEFL test except for academic purpose" (47.7) and "the tuition fee of TOEFL test is expensive" (43.2\%). The table shows most respondents disagree to statement items 1, 4, and 5. Interestingly, 
the other statements were thought neutral dominantly. It means that students did not still believe that TOEFL is important for academic purposes.

4.1.2. Students' Readiness to the TOEFL Policy

To answer the second research question, the data were taken from TOEFL scores from 1058 students who have taken the test between the years of 2018 and 2019. The detailed information is demonstrated in the following table.

Table 3. Demographic Information of TOEFL participant.

\begin{tabular}{l|lcc}
\hline \multicolumn{1}{c|}{ Category } & \multicolumn{1}{c}{ Variable } & Total (N) & Percentage (\%) \\
\hline \multirow{2}{*}{ Gender } & Male & 344 & 68 \\
& Female & 741 & 32 \\
\hline \multirow{5}{*}{ Faculty } & Agriculture & 199 & 19 \\
& Engineering & 127 & 12 \\
& Social and Political Science & 271 & 25 \\
& Economics & 199 & 19 \\
& Public Health & 148 & 14 \\
\hline Total TOEFL Participants: & 114 & 11 \\
\hline TOEFL Score: & Fisheries and Marine Science & 1058 & 100 \\
& 400 & 628 & 58 \\
& 1 & 457 & 42 \\
\hline \multirow{5}{*}{ The frequency of } & 2 & 766 & 83.81 \\
taken test: & 3 & 130 & 14.22 \\
& 4 & 15 & 1.64 \\
& 5 & 2 & 0.22 \\
& & 1 & 0.11 \\
\hline
\end{tabular}

This table was adopted from Hsieh (2017) who examined student strategies in taking the TOEIC test. Based on this demographic information, it can be concluded that the number of students who meet the minimum standard criteria is only $42 \%$. It is categorized as not ready to face the TOEFL score policy as a graduation requirement. The average frequency of the tests taken was once (83.81\%). In other words, students must meet 400 as the minimum standard score to attend the script examination. Based on the result, it is implied that students are not ready for the policy. From the total TOEFL score obtained by Universitas Teuku Umar students, it can be implied that they failed to reach the minimum of TOEFL standard criteria for exit requirement (58\%).

\section{Conclusion}

In conclusion, the questionnaire result the majority of undergraduate students have low ability to master English and English environment support. Most of them are aware of the importance of learning English, which is proven from the majority of them agree that the implementation of the TOEFL is a graduation requirement and they get to benefit from learning TOEFL. The majority of students agree that the TOEFL motivates them to study abroad and to sharpen their English ability. Based on the TOEFL score taken from 2018-2019, undergraduate students are not ready yet for the TOEFL policy as a graduation requirement. It is proven from most of them still got under the minimum criteria of the score. It is recommended that the university decision-makers periodically review the cut scores to ensure that the requirements are appropriate for their students and the intended purpose of the exam. Students are expected to prepare the policy by deepening English skills by self-learning, taking the course, or building an English environment on the campus.

\section{References}

Al-Rawadesheh, H. (2010). Difficulties that face graduate students during their TOEFL preparation program at Jordanian university. Abhath Al-Yarmouk Hum. \& Soc. Sci, 2307-2329.

Arikunto, S. (2006). Prosedur penelitian: suatu pendekatan praktik. Jakarta: Rineka Putra. 
Chen, M-L \& Squires, D. (2010). Vocational college students' standardized English proficiency test. The Asian EFL Journal Quarterly, 12 (2): 68-91.

Chen, L. H-M. (2002, Oktober). Mixed Ability ESL Class Management in Taiwan Middle High Schools. In Proceedings of the Sixth Cross-Strait Foreign Languages Conference (pp. 307-322). Taipei County, Taiwan.

Chu H-Y. (2009). Stakes, needs and washback: An investigation of the English benchmark policy for graduation and EFL education at two universities of technology in Taiwan. PhD dissertation. Taipei: National Taiwan Normal University.

Devira, M \& Makhroji. (2017). The EFL university students' problem in answering the test of English as a foreign language (TOEFL): a study in Indonesian context. In the Proceeding of International Conference on Science, Technology and Modern Society. 1(1), 93-97.

English Testing Service. (2006). Test of English as A Foreign Language (TOEFL). Princeton, New Jersey: Educational Testing Service.

Hamid, M.O \& Nguyen, H.T.M. (2016). Globalization, English language policy and teacher agency: focus on Asia. The International Educational Journal: Comparative Perspective, 15 (1): 26-44.

Hsieh, C. N. (2017). The case of Taiwan: Perceptions of college students about the use of the TOEIC tests a condition of graduation (Research Report No. RR-17-45). Princeton, NJ: Educational Testing Service.

Huda, N. (2000). Kedudukan dan fungsi bahasa asing (The Position and Function of Foreign Languages). In H. Alwi dan D. Sugono, Politik Bahasa: Risalah Seminar Politik Bahasa (Language Politics: Procedings of the Seminar on Language Politics), 59-78. Jakarta: Pusat Bahasa dan Departemen Pendidikan Nasional.

Kasim, U. (2016, November). The implementation of TOEFL score as a requirement for script examination at Syiah Kuala University. In Proceedings of English Education International Conference (Vol. 1, No. 2, pp. 24-28).

Komari. 2008. Kemampuan bahasa Inggris mahasiswa tingkat akhir Universitas Sains dan Teknologi Jayapura berdasarkan skor TOEFL. Jurnal Dinamis. Vol. 2 No. 12 Desember 2008, 47-51.

Mahmud, M. (2014). The EFL students' problems in answering the Test of English as a Foreign Language (TOEFL): A study in Indonesian context. Theory and Practice in Language Studies, 4(12): 25812587.

Pan, Y-C \& Newfields, T. (2012). Tertiary EFL Proficiency graduation requirement in Taiwan: a study of washback on learning. Electric Journal of Foreign Language Teaching. 9 (1), 108-122.

Rahma, E.A \& Setiyana, R. (2020). Students' motivation of Learning English at Teuku Umar University. Journal of English Language, Literature and Teaching. 4 (1), p. 27-32.

Salam, U, Fergina, A \& Suparjan. (2012). Kebijakan toefl di universitas tanjungpura. Guru Membangun, 28 (2): 13-15.

Samad, I. A \& Fitriani, S. S. (2016). English proficiency in facing ASEAN economic community: an opportunity or a challenge? Proceedings of the 6th Annual International Conference Syiah Kuala University (AIC Unsyiah) in conjunction with the 12th International Conference on Mathematics, Statistics and Its Application (ICMSA), October 4-6, Banda Aceh, Indonesia.

Sharpe, P. J. (2004). How to prepare for the TOEFL: Test of English as a foreign language. New York: Barron's Educational Series, Inc.

Sindkhedkar. (2012). Objectives of teaching and learning English in India. Journal of Arts, Science \& Commerce, 3 (1): 191- 194.

Shih, P.C. (2013). The English Benchmark Policy for Graduation: An Investigation of Perception, Motivation, and Approaches to Learning at a University of Technology in Central Taiwan, Durham theses, Durham University. Available at Durham E-Theses Online: http://etheses.dur.ac.uk/8512/.

Shih, C.-M. (2012). Policy analysis of the English graduation benchmark in Taiwan. Perspectives in Education, 30(3), 60-68. 
2010. The washback of the general English proficiency test on university policies: a taiwan case study. Language Assessment Quarterly, 7: 234-254.

----------. 2007. A new washback model of students' learning. Canadian Modern Language Review, 64: 135-162.

Shohamy, E., Donitsa-Schmidt, S., \& Ferman, I. (1996). Test impact revisited: Washback effect over time. Language Testing, 13(3), 298-317.

Wahab, A. S. 2004. Analisis Kebijakan dari formulasi ke implementasi kebijaksanaan negara. Jakarta: Bumi Aksara. 